\title{
Fermentasi: Metode untuk Meningkatkan Nilai Nutrisi Jerami Padi
}

\author{
Fermentation: Methods to Improve Nutrition Value of Rice Straw
}

\author{
Yanuartono, S. Indarjulianto, H. Purnamaningsih, A. Nururrozi, dan S. Raharjo \\ Departemen Ilmu Penyakit Dalam, Fakultas Kedokteran Hewan Universitas Gadjah Mada. \\ J1. Fauna No.2, Karangmalang, Depok, Sleman. 55281 Yogyakarta \\ Corresponding e-mail : yanuartono@ugm.ac.id
}

\begin{abstract}
Most of the ruminant livestock rations in Southeast Asia come from grain crops residues. Rice straw is the main crop residue which farmers usually store and use as ruminant feed in tropical areas especially during the long dry season whereby natural forages are being in constraint. However, feeding rice straw does not provide adequate nutrition for ruminants even for basic living because of its low nutritional value. The nutritional value of rice straw is limited by low levels of intake and slow digestibility and low levels of energy, protein, minerals and vitamins. Various types of treatments to improve the nutritional value of rice straw have been widely carried out including physical, biological and chemical methods. One of them is the fermentation technology that can improve the nutrition of rice straw. This review aims to describe the practical aspects of the fermentation process based on the results of previous study on rice straw to increase its nutritional value.
\end{abstract}

Keywords :livestock, rice straw, ruminant, nutritive value, fermentation.

\begin{abstract}
ABSTRAK
Sebagian besar ransum ternak ruminansia di Asia Tenggara berasal dari limbah tanaman bijian. Jerami padi adalah limbah utama yang biasanya disimpan dan digunakan oleh peternak sebagai pakan ternak ruminansia di daerah tropis saat musim kemarau panjang dimana hijauan segar sulit diperoleh. Namun demikian, pemberian pakan jerami padi tidak memberikan nutrisi yang cukup untuk ruminansia bahkan untuk hidup pokok karena nilai gizi yang rendah. Nilai gizi jerami padi dibatasi oleh rendahnya tingkat asupan dan lambatnya kecernaan serta rendahnya kandungan energi, protein, mineral dan vitamin. Berbagai macam metode perlakuan telah digunakan untuk meningkatkan nilai gizi jerami padi termasuk fisik, biologis dan kimiawi. Salah satu diantaranya adalah teknologi fermentasi yang dapat meningkatkan nutrisi jerami padi. Ulasan ini bertujuan untuk memaparkan aspek praktis dari proses fermentasi berdasarkan hasil hasil penelitian terdahulu tentang jerami padi untuk meningkatkan nilai gizinya.
\end{abstract}

Kata kunci: ternak, jerami padi, ruminansia, nilai nutrisi, fermentasi

\section{PENDAHULUAN}

Jerami padi merupakan salah satu alternatif yang memiliki potensi menjadi pakan ternak pada kondisi tertentu. Potensi jerami padi tersebut ditunjukkan oleh ketersediaannya yang melimpah dan sebagian besar cenderung tidak termanfaatkan. Sayangnya, proses pembuangan yang sering dilakukan adalah pembakaran di lahan pertanian sehingga akan menimbulkan pencemaan udara. Data dari Litbang pertanian (2012) menunjukkan bahwa limbah jerami yang tidak dimanfaatkan karena dibakar sebesar $37 \%$ dan digunakan sebagai kompos dari alas kandang 36\%. Lebih lanjut, hanya sekitar $15 \%$ - 22\% dimanfaatkan sebagai sumber pakan ternak. Sedangkan menurut Masnun (2014), pemanfaatan jerami padi sebagai pakan baru mencapai $31-39 \%$, selainnya adalah untuk dibakar atau dikembalikan ketanah 36-62 \%, serta untuk industri 7-16\%. Pemanfaatan jerami sebagai pakan hewan pakan memiliki kelemahan utama pada daya cerna serta nilai gizi yang rendah. Daya cerna yang rendah tersebut disebabkan karena tingginya kandungan lignoselulosa, lignin dan silika, sedangkan nilai gizi yang rendah terutama disebabkan karena sedikitnya 
kandungan energi, protein, mineral dan vitamin (Sarnklong et al., 2010 ; Yanuartono et al., 2017). Meskipun demikian, kelemahan kelemahan tersebut dapat diantisipasi melalui berbagai metode perlakuan untuk meningkatkan nilai gizinya. Jerami padi dapat ditingkatkan kualitasnya melalui berbagai macam teknologi. Sudah sejak lama berbagai upaya telah dilakukan untuk meningkatkan kecernaan dan pemanfaatan residu pertanian termasuk jerami padi (Wanapat et al., 1996). Upaya penerapan tersebut ditekankan pada pemanfaatan teknologi yang bersifat praktis dan ekonomis supaya mudah dilakukan terutama oleh peternak skala kecil. Berbagai penelitian tentang inovasi teknologi yang terkait dengan pemanfaatan jerami padi sebagai sumber pakan berserat bagi ternak ruminansia sudah banyak dilaporkan (Kargbo et al., 2009). Sampai saat ini, metode yang telah banyak dilakukan untuk meningkatkan nilai nutrisi jerami padi adalah perlakuan fisik (Missotten et al., 2010), kimiawi (Han and Garret 1986; Ismail et al., 2012) dan biologis (Mahesh and Mohini 2013; Wang et al., 2016).Menurut Van Soest (2006), metode biologis dan kimia merupakan metode pilihan yang paling sering digunakan.

Salah satu metode pengolahan jerami sebagai pakan ternak yang sederhana, murah dan dapat dilakukan adalah fermentasi. Hasil hasil penelitian dengan menggunakan metode fermentasi jerami padi pada umumnya menunjukkan adanya peningkatan kualitas nilai nutrisinya. Metode fermentasi jerami padi telah banyak diterapkan di kelompokkelompok ternak oleh lembaga Pemerintah maupun Perguruan Tinggi melalui penyuluhan dan pengabdian masyarakat. Tulisan ini bertujuan untuk mengulas manfaat proses fermentasi yang bertujuan meningkatkan nilai nutrisi jerami padi sebagai pakan ternak ruminansia.

\section{Limbah Jerami Padi}

Jerami merupakan bagian vegetatif berupa batang, daun, dan tangkai dari tanaman padi dan merupakan limbah pertanian terbesar di Indonesia (Setiarto,
2013). Produksi jerami padi bisa mencapai 12-15 ton per ha/satu kali panen atau 4-5 ton bahan kering tergantung pada lokasi dan varietas yang digunakan (Yunilas, 2009). Hasil penelitian Haryanto et al. (2002) menunjukkan bahwa produski jerami segar setiap hektar mencapai12-15 ton/ha/musim dan dapat menghasilkan 5-8 ton/ha setelah melalui proses fermentasi. Ketersediaan jerami mencapai kisaran 55 juta ton setahun namun baru sekitar 31-32\% yang dimanfaatkan sebagai pakan ternak (Syamsu, 2006; Setiarto, 2013). Jerami padi selain sebagai bahan pembuatan pupuk dan sumber pakan ternak (Pane et al., 2014; Asmin dan La Karimuna, 2014), melalui sentuhan teknologi, jerami padi masih memiliki banyak potensi bagi kehidupan masyarakat diantaranya dapat diolah menjadi sumber energi alternatif seperti biogas (Romli et al., 2014; Dehghani et al., 2015) maupun bioetanol (Yoswathana et al., 2010; Roslan et al., 2011). Berdasarkan produksi yang melimpah tersebut jerami padi memiliki potensi untuk diproses guna meningkatkan nilai manfaatnya sebagai pakan ternak.

Menurut Himmel and Picataggio (2008), jerami padi sebagian besar tersusun dari lignoselulosa dan lignohemiselulosa yang sukar dicerna oleh ternak ruminansia serta mengandung silikat dan oksalat tinggi. Silika dalam jumlah yang cukup tinggi tersebut menghalangi kemampuan mikroba rumen untuk mencernanya. Jorgensenand Olsson (2006) menyatakan bahwa lignoselullosa sendiri tersusun atas sellulosa $35-50 \%$, hemisellulosa $25-30 \%$ dan lignin 25-30\%. Sedangkan menurut Srithongkham et al. (2012) jerami padi mengandung sellulosa 30-35\%, hemisellulosa 25-30\%, lignin $15-28 \%$ dan abu 4-7\%. Menurut Drake et al. (2002) jerami padi mempunyai kandungan PK 2-7\%, lignin 6-7\% dan silika 12-16\%. Sharma et al. (2001) dan Ganai et al. (2006) menyatakan bahwa jerami padi memiliki kandungan $25-45 \%$ sellulosa, 25 $30 \%$ hemisellulosa dan 10-15\% lignin akan tetapi kandungan nitrogen, vitamin dan mineral rendah. Kandungan protein jerami padi berada dalam kisaran 4,5-4,5\%, lebih 
rendah jika dibandingkan dengan kandungan protein rumput $(5-9 \%)$ sehingga jika digunakan sebagai pakan ternak dalam jangka waktu yang panjang kemungkinan akan berdampak buruk (Martawidjaja, 2003; Bakshi and Wadhwa, 2017).

\section{Metode Fermentasi Jerami Padi}

Menurut Iglesias et al. (2014) fermentasi merupakan proses yang memanfaatkan mikroba dengan tujuan merubah substrat menjadi produk tertentu seperti yang diharapkan. Menurut Chilton et al., (2015) definisi pakan fermentasi adalah pakan yang diberi perlakuan dengan penambahan mikro-organisme atau enzim sehingga terjadi perubahan biokimiawi dan selanjutnya akan mengakibatkan perubahan yang signifikan pada pakan. Jerami padi tersedia hampir sepanjang tahun sehingga dapat digunakan sebagai sumber pakan ternak pada saat produksi melimpah. Guna menyediakan pakan ternak secara kontinyu, diperlukan suatu teknologi pengawetan tanpa menurunkan kandungan nutrisinya. Fermentasi merupakan salah satu metode untuk meningkatkan nilai nutrisi yang sesuai dengan karakteristik jerami padi karena prosesnya relatif mudah serta hasilnya bersifat palatable sehingga lebih mudah diberikan pada ternak ruminansia (Liu et al., 2015). Fermentasi jerami tidak hanya dapat meningkatkan manfaatnya akan tetapi juga mampu mengurangi polusi karena proses pembakaran di lading sehingga diharapkan dapat menjaga efek keseimbangan ekologis (Baiet al., 2017). Namun demikian, diperlukan upaya yang besar untuk meningkatkan kualitas fermentasi karena rendahnya kandungan karbohidrat terlarut pada jerami (Zahiroddini et al., 2004; Belal, 2013). Penambahan substrat fermentasi baik secara langsung maupun tidak langsung merupakan salah satu metode yang dapat dilakukan guna meningkatkan kualitas hasil fermentasi (Zhang et al., 2010; Malik et al., 2015). Metode penambahan substrat fermentasi baik secara langsung maupun tidak langsung sebagai upaya untuk meningkatkan kualitas fermentasi telah banyak dilakukan. Salah satu faktor yang mempengaruhi keberhasilan suatu fermentasi adalah suhu. Pada suhu yang tepat mikroorganisme akan dapat tumbuh dan berkembang dengan baik. Disamping itu, fermentasi jerami padi dapat berjalan dengan baik dalam kondisi aerob maupun anaerob dan didominasi oleh bakteri penghasil asam laktat yang bersifat fakultatif anaerob (Mussoline et al., 2012). Fermentasi jerami dapat dilakukan dengan proses anaerob memanfaatkan campuran beberapa bakteri seperti bakteri proteolitik (Watanabe and Hayano, 1993), lignolitik, selulolitik (Wanapat et al., 2013; Saritha et al., 2015), lignoselulolitik dan lipolitik (Kausar et al., 2010). Bakteri tersebut dapat dimanfaatkan sebagai starter inokulandan berperan meningkatkan nilai nutrisi jerami karena memiliki kemampuan untuk menghasilkan enzim laktase, selulase, maupun xilanase yang secara berturut-turut mampu menghidrolisis senyawa lignin, selulosa maupun hemi selulosa yang banyak terkandung dalam jerami padi (Howard et al.,2003; Mishra and Pandey, 2007; Aggarwal et al., 2017). Selain kemampuan tersebut diatas, fermentasi mikroba juga dapat meningkatkan palatabilitas, asupan pakan dan kinerja ternak (Colombatto et al., 2007; Gado et al., 2011).

Produk additive komersial yang telah dikembangkan dan banyak digunakan untuk proses fermentasi pada pembuatan silase adalah lactic acid bacteria (LAB)/ bakteri asam laktat (BAL) dan enzim selulase (Sun et al.,2009; Napasirth et al., 2015). Bakteri asam laktat (BAL) komersial telah lebih dari 20 tahun digunakan sebagai inokulan pada proses fermentasi pembuatan silase dan saat ini semakin mudah diperoleh karena makin banyak diproduksi oleh perusahaan (Ashraf and Smith, 2016; Yazdi et al., 2017). Namun demikian kenyataan dilapangan menunjukkan bahwa tidak semua BAL komersial cocok digunakan di lingkungan yang berbeda dengan asalnya (Filya dan Sucu, 2007). Tujuan pemberian additive BAL adalah mempercepat pembentukan asam laktat dan asetat guna mencegah 
terbentuknya fermentasi yang tidak dikehendaki (Ennahar et al., 2003). Lebih lanjut, produksi asam laktat menghasilkan suasana asam di dalam lingkungan fermentasi anaerob, nilai akhir $\mathrm{pH}$ sekitar 4 dan hasil fermentasi dapat disimpan dalam waktu lama tanpa ada pembusukan. Oladosu et al. (2016) menambahkan bahwa penambahan bakteri asam laktat yang tumbuh cepat ditujukan untuk mendominasi seluruh proses fermentasi. Banyaknya bakteri asam laktat akan membantu menghambat pertumbuhan bakteri pembusuk dan mempertahankan kualitas massa jerami yang difermentasi. Sebagai indikator kualitas fermentasi jerami padi adalah tingginya kadar asam-asam asetat, propionat, dan butirat (Volatile Fatty Acids) (Ohmomo et al.,2002; Hidanah et al., 2016).

Amoniasi merupakan salah satu metode yang telah banyak diterapkan untuk meningkatkan nilai nutrisi jerami. Amoniasi dengan menggunakan urea dapat meningkatkan kandungan gizi dan memiliki kemampuan mencerna limbah serat. Ammoniasi melibatkan dapat melarutkan hemiselulosa, silica dan mengurangi kandungan lignin dari dinding sel (Sheikh et al., 2018). Hasil penelitian Hart and Wanapat (1992) menunjukkan bahwa pemberian urea $5 \%$ dalam jerami padi dapat meningkatkan laju partikel pakan dalam rumen, kecernaan dan produksi VFA. Pengembangan dari metode tersebut adalah amoniasi dan fermentasi (amofer) yang bertujuan untuk lebih meningkatkan nilai nutrisi jerami. Teknik amofer memanfaatkan urea untuk proses amoniasi dan bakteri asam laktat (BAL) dalam proses fermentasi. Menurut Mayulu (2014) metode amofer memiliki kemampuan untuk memecah selulosa, hemiselulosa dan kandungan lignin jerami padi sehingga lebih mudah dicerna.

Kelemahan proses fermentasi adalah tingginya tingkat kelembaban yang sering mengakibatkan penurunan nilai gizi dan munculnya kontaminasi aflatoksin. Jerami padi yang digunakan sebagai pakan ternak dapat terkontaminasi aflatoksin sehingga menyebabkan aflatoxicosis pada sapi. Azab et al. (2005) dalam penelitian menyatakan adanya $A$. flavus pada $28 \%$ sampel jerami padi. Sedangkan hasil penelitian Bhuiyan et al. (2003) menunjukkan bahwa kelembaban tinggi pada fermentasi jerami padi mengakibatkan turunnya kandungannya nutrisi terlarut, daya cerna in vitro, degradasi bahan kering. Kelembaban juga mengakibatkan transmisi aflatoksin dari jerami yang difermentasi ke dalam susu meskipun dalam kadar yang rendah. Perbedaan kondisi lingkungan, sistem pertanian, penyimpanan dan praktek penanganan jerami padi mendukung pertumbuhan jamur dan pembentukan aflatoksin (Whitlow et al., 2002)

\section{Dampak Fermentasi terhadap Nilai Nutrisi Jerami}

Pemberian jerami padi sebagai pakan tunggal tidak akan pernah mampu menyediakan nutrien yang cukup bagi kebutuhan ruminansia. Pada dasarnya, kunci untuk meningkatkan nilai nutrien pada limbah tanaman seperti jerami padi adalah mengatasi hambatan utama pada proses fermentasi oleh mikroba rumen. Hasil penelitian Amin et al. (2015) menunjukkan bahwa fermentasi jerami selama 30 jam mampu meningkatkan kadar PK (9,31\%), kecernaan bahan kering $(38,40 \%)$, dan bahan organik (42,93\%), serta menurunkan NDF $(73,45 \%)$, ADF $(55,45 \%)$, selulosa $(13,81 \%)$, hemiselulosa $(18,00 \%)$ dan lignin $(16,77 \%)$. Penurunan kandungan NDF jerami padi hasil fermentasi kemungkinan diakibatkan oleh aktifitas enzim selulase yang dihasilkan oleh mikroba. Enzim tersebut mendegradasi, merombak, melonggarkan serta memutuskan ikatan lignosellulosa dan lignohemisellulosa (Jeya, et al., 2009). Penelitian Basuni et al, (2010) juga menunjukkan bahwa fermentasi jerami padi dapat meningkatkan kandungan PK menjadi $9,09 \%$ serta menurunkan serat menjadi 18,44\%. Lebih lanjut, Bansi et al. (2012) dalam penelitiannya menyatakan bahwa fermentasi jerami padi mampu meningkatkan kandungan PK menjadi sebesar 8,79\% dan menurunkan kandungan serat kasar menjadi 39,96\%. Jerami padi 
kering dapat difermentasi dan kemudian diolah menjadi complete feed (pakan komplet) dengan menambahkan bekatul atau bahan lain sehingga kadar protein mengalami peningkaan dari $3-4 \%$ menjadi $7-8 \%$ (Suwignyo, 2003). Hasil penelitian-penelitian tersebut didukung oleh Mulijanti et al. (2014) yang menyatakan bahwa fermentasi jerami padi mampu meningkatkan kandungan PK menjadi $10,48 \%$ dan menurunkan serat kasar menjadi 16,74\%. Hasil penelitian Yanti et al. (2008) menunjukkan bahwa fermentasi dengan mikroorganisme seperti Lactobacillus fermentum, Bacillus subtilis, Bacillus coagulant, Saccharomyces cerevisiae, Aspergillus niger dapat meningkatkan PK serta menurunkan nilai BK. Kemampuan bakteri asam laktat (BAL) untuk mengubah nitrogen non protein menjadi protein akan mengakibatkan terjadinya peningkatan kadar PK jerami padi fermentasi (Bureenok et al.,2005).

\section{Dampak Pemberian Fermentasi Jerami Terhadap Produktivitas Ternak}

Pemanfaatan jerami padi sebagai pakan akan sangat membantu petani dalam mengatasi masalah kekurangan pakan hijauan terutama pada musim kering yang panjang, terutama bagi usaha peternakan rakyat yang pada umumnya berskala kecil. Banyak hasil penelitian menunjukkan bahwa pemberian pakan menggunakan fermentasi jerami padi dapat meningkatkan produktivitas ternak ruminansia besar maupun kecil. Hasil penelitian Sutama et al. (2006) menunjukkan kambing PE yang diberi pakan basal jerami padi fermentasi dengan penambahan konsentrat dapat menggantikan peran rumput segar sebagai sumber serat. Kambing PE tersebut menunjukkan kinerja, produksi susu, bobot lahir anak, pertumbuhan pra-sapih dan bobot sapih yang hampir sama dengan kambing PE yang diberi pakan rumput segar. Penelitian dengan menggunakan sapi bali juga menunjukkan hasil cukup memuaskan. Hasil penelitian (Sugama dan Budiari, 2012) menunjukkan bahwa pakan jerami fermentasi yang dikombinasikan dengan hijauan ditambah 1 $\mathrm{kg}$ dedak padi/ekor/hari serta probiotik mampu meningkatkan pertambahan berat badan harian sapi dara betina, body condition score (BCS), berat lahir pedet, menurunkan angka Service per conception (S/C) tubuh ternak serta jika dibandingkan dengan pakan rumput/HMT Sheikh et al. (2017) dalam penelitiannya menunjukkan bahwa jerami padi yang ditambah urea molase dapat meningkatkan status gizi, berat badan, konsumsi pakan domba Corriedale. Hasil penelitian Utomo (2004) menunjukkan tidak adanya perubahan pada produktivitas ternak yang diberi pakan jerami padi fermentasi dibandingkan dengan jerami padi tanpa fermentasi.

Tabel 1. Dampak pemberian fermentasi Jerami padi terhadap produktivitas ternak

\begin{tabular}{|c|c|c|c|}
\hline Jenis ternak & Pakan & Dampak & Pustaka \\
\hline $\begin{array}{l}\text { Holstein } \\
\text { crossbred }\end{array}$ & $\begin{array}{l}\text { Jerami padi fermentasi } \\
+ \text { konsentrat }\end{array}$ & $\begin{array}{l}\text { Peningkatan asupan pakan dan } \\
\text { produksi susu }\end{array}$ & Wanapat et al., 2013 \\
\hline Sapi jantan & $\begin{array}{l}\text { Jerami }+ \text { urea molase }+ \\
\text { konsentrat }\end{array}$ & $\begin{array}{l}\text { peningkatan asupan pakan dan } \\
\text { peningkatan ADG }\end{array}$ & Rahman et al., 2009 \\
\hline Domba & $\begin{array}{l}\text { Jerami padi fermentasi } \\
+ \text { urea molase }\end{array}$ & Peningkatan asupan bahan kering & Alam et al., 2016 \\
\hline Sapi perah & $\begin{array}{l}\text { Jerami padi fermentasi } \\
+ \text { pellet alfalfa }\end{array}$ & Peningkatan asupan bahan kering & $\mathrm{Na}$ et al., 2014 \\
\hline Sapi potong & $\begin{array}{l}\text { jerami padi fermentasi } \\
+ \text { dedak padi }\end{array}$ & Peningkatan ADG & Mulijanti et al., 2014 \\
\hline Kerbau & $\begin{array}{l}\text { Jerami padi fermentasi } \\
+ \text { konsentrat }\end{array}$ & Peningkatan asupan bahan kering & Kaur et al., 2008 \\
\hline Sapi potong & $\begin{array}{l}\text { Hijauan }+ \text { Jerami } \\
\text { Fermentasi }+ \text { Mineral } \\
\text { blok }+ \text { Konsentrat }\end{array}$ & Peningkatan ADG & Yusriani et al., 2015 \\
\hline
\end{tabular}


Penelitian pada domba yang diberi pakan jerami padi fermentasi tidak menunjukkan perbedaan ADG dan konversi pakan dibandingkan dengan domba yang diberi pakan rumput dan jerami padi tanpa fermentasi. Hasil yang berbeda ditunjukkan oleh penelitian El-Bordeny et al. (2015) yang menyatakan bahwa domba yang diberi pakan jerami padi fermentasi menunjukkan konversi pakan dan ADG yang lebih baik dibandingkan dengan pemberian jerami padi tanpa fermentasi. Hasil penelitian tersebut kemungkinan disebabkan oleh respon positif dalam pemanfaatan nutrisi, keseimbangan nitrogen serta pertambahan bobot badan terkait dengan pemanfaatan jerami padi melalui proses pengolahan biologis atau fermentasi oleh mikrorganisme tertentu (Khattab et al. 2009; Shrivastava et al. 2012). Lebih lanjut, selama proses fermentasi terjadi perombakan karbohidrat terstruktur dan non terstruktur sehingga terjadi peningkatan kandungan protein kasar jerami padi (Utomo, 2004).

Tabel 1 menunjukkan bahwa penelitian yang dilakukan menggunakan jerami padi ditambah dengan bahan pakan lain sebagai pendukung. Jerami padi tampaknya tidak pernah diberikan sebagai pakan basal tunggal dalam penelitian yang terkait dengan manfaat jerami padi, baik yang difermentasi maupun tanpa fermentasi. Menurut Shanahan et al. (2004), penambahan bahan pakan yang memiliki kualitas tinggi seperti konsentrat dapat dilakukan untuk mengatasi penggunaan jerami padi jika digunakan sebagai pakan basal sehingga diharapkan dapat meningkatkan produktivitas ternak. Kenyataan tersebut menunjukkan masih diperlukannya penelitian yang lebih mendalam mengenai metode pemrosesan untuk lebih meningkatkan nilai nutrisi jerami padi.

\section{KESIMPULAN}

Pemanfaatan jerami sebagai pakan hewan pakan memiliki kelemahan utama pada daya cerna serta kandungan protein rendah yang rendah, meskipun dapat ditingkatkan kualitasnya melalui berbagai macam metode pengolahan. Salah satu metode pengolahan jerami sebagai pakan ternak yang sederhana, murah dan dapat dilakukan adalah fermentasi. Secara umum, fermentasi jerami padi dapat meningkatkan nilai nutrisinya sehingga jika diberikan sebagai pakan akan mampu meningkatkan produktivitasnya. Metode fermentasi jerami padi juga harus diteliti dan dievaluasi lebih mendalam untuk mendapatkan produk yang bebas dari bahan toksik seperti aflatoksin.

\section{DAFTAR PUSTAKA}

Aggarwal, N.K., V. Goyal, A. Saini, A. Yadav and R. Gupta. 2017. Enzymatic saccharification of pretreated rice straw by cellulases from Aspergillus niger BK01. 3 Biotech 7 (158) 1-10. DOI 10.1007/s13205-017-0755-0

Alam, M.K., Y. Ogata, Y. Sato and H. Sano. 2016. Effects of Rice Straw Supplemented with Urea and Molasses on Intermediary Metabolism of Plasma Glucose and Leucine in Sheep. AsianAustralasian Journal of Animal Sciences. $29 \quad$ (4) :523-529. doi:10.5713/ajas.15.0358.

Amin, M., S.D.Hasan, O. Yanuarianto dan M. Iqbal. 2015. Pengaruh lama fermentasi terhadap kualitas jerami padi amoniasi yang ditambahprobiotik Bacillus Sp. Jurnal Ilmu dan Teknologi Peternakan Indonesia. 1 (1) : 8-13. ISSN : 2460-6669

Ashraf, R. and S.C. Smith. 2016. Commercial lactic acid bacteria and probiotic strains- tolerance to bile, pepsin and antibiotics. International Food Research Journal 23(2): 777-789

Asmin dan La Karimuna, 2014. Kajian pemupukan Kalium dengan aplikasi jerami padi terhadap pertumbuhan dan produksi padi sawah pada lahan sawah bukaan baru di Kabupaten Buton, Sulawesi Tenggara. JURNAL AGROTEKNOS. 4 No. (3) : 180-188

Azab, R.M., W.M. Tawakkol, A.M. Hamad, M.K. Abou-Elmagd, H.M. El-Agrab 
and M.K. Refai. 2005. Detection and estimation of aflatoxin B1 in feeds and its biodegradation by bacteria and fungi. Egy. J. Nat. Toxins, 2: 39-56.

Bai, B., C.G. Yan and G.C. Li. 2017. Study on the Characteristics of Straw Fermentation by Bacillus megaterium MYB3. Earth and Environmental Science 81 (1) : 1-7.doi :10.1088/17551315/81/1/012010

Bakshi, M.P.S. and M. Wadwha.2017. Utilization of rice-straw as livestock feed. Indian farming 67(07): 27-29.

Bansi, H., R. Risiyanto and R. A. Indriawaty. 2012. Use Of Microbes To Improve Nutritional ValueOf Rice Straw. International Conference on Livestock Production andVeterinary Technology 2012: 99-103.

Basuni, R., Muladno, C. Kusmana dan Suryahadi.2010. Model sistem integrasi padi sapi potong di lahan sawah. Forum Pasca Sarjana. 33 (3) : 177-190

Belal, E.B. 2013. Bioethanol production from rice straw residues. Brazilian Journal of Microbiology 44, 1, 225234.DOI: $10.1590 / \mathrm{S} 1517-$ 83822013000100033

Bhuiyan, A., M. A. Akbar and M. E. Hossain.2003. Nutritive Value of Damp Rice Straw and its Feeding Effect on Aflatoxin Transmission into Cows Milk. Pakistan Journal of Nutrition 2 (3): 153-158.

DOI: $10.3923 /$ pjn. 2003.153 .158

Bureenok, S., T. Namihira, M. Tamaki, S.Mizumachi, Y. Kawamoto and T. Nakada.2005. Fermentative Quality of GuineagrassSilage by Using Fermented Juice of theEpiphytic Lactic Acid Bacteria (FJLB) as aSilage Additive. Asian-Aust. J. Anim. Sci. 18 (6):807811.

DOI: https://doi.org/10.5713/ajas.2005. $\underline{807}$

Chilton, S.N., J.P. Burton and G. Reid. 2015. Inclusion of Fermented Foods in Food Guides around the World. Nutrients 7: 390-404. doi:10.3390/nu7010390
Colombatto, D., F.L. Moulda, M.K. Bhat and E. Owena. 2007. Influence of exogenous fibrolytic enzyme level and incubation $\mathrm{pH}$ on the in vitro ruminal fermentation of alfalfa stems. Animal Feed Science Technology. 137 (1-2): 150-162.

https://doi.org/10.1016/j.anifeedsci.200 $\underline{6.10 .001}$

Dehghani, M., K. Karimiand M.Sadeghi. 2015.Pretreatment of Rice Straw for the Improvement of Biogas Production. Energy Fuels. 29 (6):3770-3775 DOI: 10.1021/acs.energyfuels.5b00718

Drake, D.J., G. Nader and L. Forero. 2002.Feeding Rice Straw to Cattle. ANRPublication 8079. University of California.

El-Bordeny, N.E., H.M. Khattab, A.M. ElBadr and M.A. Madkour. 2015. Using of Bio-Upgraded Rice Straw in Growing Lambs Nutrition. Asian Journal of Animal and Veterinary $\begin{array}{llll}\text { Advances. } \quad 10 & \text { (2): } \quad 62-73 .\end{array}$ DOI: 10.3923/ajava.2015.62.73

Ennahar, S., Y. Cai and Y. Fujita. 2003. Phylogenetic diversity of lactic acid bacteria associated with paddy rice silage as determined by $16 \mathrm{~S}$ ribosomal DNA analysis. Applied and Environmental Microbiology. 69 (1): 444-451. doi: 10.1128/AEM.69.1.444451.2003

Filya, I. and E. Sucu. 2007. The effect ofbacterial inoculants and a chemicalpreservative on the fermentation andaerobic stability of whole-crop cerealsilages. Asian-Aust. J. Anim. Sci. 20 (3): 378 -384. DOI: https://doi.org/10.5713/ajas.2007. $\underline{378}$

Gado, H.M., A.Z.M. Salem, N.E. Odongo and B.E. Borhami. 2011. Influence of exogenous enzymes ensiled with orange pulp on digestion and growth performance in lambs. Animal Feed Science Technology. 165 (1-2): 131136.

https://doi.org/10.1016/j.anifeedsci.201 1.02 .016 
Ganai, A.M., F.A. Matoo, P.K. Singh, H.A. Ahmad and M.H. Samoon. 2006. Chemical composition of some feeds, fodders and plane nutrition of livestock of Kashmir valley. SKUAST Journal Res 8:145-151.

Han, I.K. and W.N. Garret. 1986. Improving the dry-matterdigestibility and voluntary intake of low-quality roughageby various treatments: a review. Korean J Anim Sci 28: 89-96.

Hart, F. J. and M. Wanapat. 1992. Physiology of digestion of urea-treated rice straw in swamp buffaloes. AsianAus. J. Anim. Sci. 5 (4):617-622. DOI: https://doi.org/10.5713/ajas.1992. 617

Haryanto, B., I. Inounu, I.G.M. Budiarsana dan K. Dwiyanto. 2002. Panduan Teknis Sistem Integrasi Padi-Ternak. Jakarta: Badan Penelitian dan Pengembangan Departemen Pertanian.

Hidanah, S., D.S.Nazar, K.Supranianondo, R. Sidik dan S. Mangkoedihardjo. 2016. Volatile Fatty Acids and Ammonia Levels in Local Sheep's Rumen Fluid Fed with Fermented Rice Straw. International Journal of Engineering and Technology (IJET). 8 (2): 13241328.

Himmel, M.E. and S.K.Picataggio. 2008. Our challenge is to acquire deeperunderstanding of biomass recalcitrance and conversion, in: M.E. Himmel(Ed.), Biomass recalcitrance. Deconstructing the Plant Cell Wall for Bioenergy,Blackwell Publishing, USA, 2008.

Howard, R.L., E. Abotsi, J.E.L. van Rensburg and S. Howard. 2003. LignocelluloseBiotechnology: Issue of Bioconversion and Enzyme Production. African J. of Biotech. Vol 2(12): $602-$ 619.DOI: 10.5897/AJB2003.000-1115

Iglesias, A., A. Pascoal, A. B.Choupina, C. A. Carvalho, X. Feás and L. M. Estevinho. 2014. Developments in the Fermentation Process and Quality Improvement Strategies for Mead Production. Molecules 19: 12577-
12590.

doi:10.3390/molecules190812577

Ismail, M., Abd El-Razik, G.A. AbdElrahman and M.S. Ayyat. 2012. Effect Of Biological And Chemical Treatments Of Rice Straw On Lamb Performance. Zagazig J. Agric. Res. 39 (4): 655-664.

Jeya, M., Y.W. Zhang, I.W. Kim and J.K. Lee. 2009. Enhancedsaccharification of alkalitreated rice straw by cellulasefrom Trametes hirsuta and statistical optimization of hydrolysis conditions by RSM. Bioresour. Technol.100 (21): 5155-5161. https://doi.org/10.1016/j.biortech.2009. 05.040

Jorgensen, H. and L. Olsson. 2006. Production of cellulases by Penicilliumbrasilianum IBT20888 Effect of substrateon hydrolytic performance. Enzyme and Microbial Technology. 38 (34): 381-390. https://doi.org/10.1016/j.enzmictec.200 5.06 .018

Kargbo, F.R., J. Xingand Y. Zhang. 2009. Pretreatment for energy use of rice straw: A review. African Journal of Agricultural Research. 4(12): 1-6.

Kaur, K., J. Kaur, M. Wadhwa, B. Kumar and M. P. S. Bakshi. 2008. Fermented Rice Straw as a Source of Nutrients for Ruminants. Indian J. Anim. Nutr. 25(3): 195-200

Kausar, H., M. Sariah, H.M. Saud, M.Z. Alam and M.R. Ismail. 2010. Development of compatible lignocellulolytic fungal consortium for rapid composting of rice straw. Int. Biodeter. Biodegr. 64 (7):594-600. https://doi.org/10.1016/j.ibiod.2010.06. $\underline{012}$

Khattab, H.M., H.M. El-Sayed, N.E. ElBordeny, O.N. Al-Asfour and M.S. Fadel. 2009. Gross performance of Barki lambs fed rations with different ratios of untreated or biologically treated wheat straw. Egypt. J. Nutr. Feed. 12: 215-228. 
Litbang Pertanian, 2012. Fermentasi Jerami untuk Pakan Ternak Sapi Edisi 19-25 September 2012 No.3474 Tahun XLIIIwww.litbang.pertanian.go.id/.../F ermentasi-Jerami-untuk-Pa.pdf

Liu, J., X. Liu, J. Ren, H. Zhao,X. Yuan,X. Wang, Z. M. S. Abdelfattahand Z, Cui. 2015. The effects of fermentation and adsorption using lactic acid bacteriaculture broth on the feed quality of rice straw.Journal of Integrative Agriculture 14(3): 503513.https://doi.org/10.1016/S20953119(14)60831-5

Mahesh, M. S. and Mohini, M. 2013. Biological treatment of crop residues for ruminant feeding: A review. Afr. J. Biotechnol. 12(27): 4221-4231.DOI: 10.5897/AJB2012.2940

Malik, K., J.Tokkas, R. C. Anand and N. Kumari. 2015. Pretreated rice straw as an improved fodder for ruminants-An overview. J. Appl. \& Nat. Sci. 7 (1) : 514-520.

DOI https://doi.org/10.31018/jans.v7i1 .640

Martawidjaja, M. 2003. Pemanfaatan Jerami Padi Sebagai Pengganti Rumput untuk Ternak Ruminansia Kecil.WARTAZOA 13 (3): 119-127.

Masnun, 2014.Teknologi Jerami Fermentasi Sebagai Pakan Ternak. www.bppjambi.info/dwnpublikasi.asp? $\mathrm{id}=135$

Mayulu, H. 2014. The nutrient potency of palm oil plantation andmill's byproductprocessed with amofer technology as ruminantfeed. International Journal of Science and Engineering (IJSE) 6 (2):112116.DOI: 10.12777/ijse.6.2.112-116

Mishra, B. K. and A. K. Pandey. 2007. Lata Lignocellulolytic Enzyme Production from Submerged Fermentation of Paddy Straw. Indian J. Microbiol. 47 (2):176-179. DOI: $10.1007 / \mathrm{s} 12088$ 007-0034-6

Missotten, J.A.M., J. Michiels, A. Ovyn, S. De Smet and N.A. Dierick. 2010. Fermented liquidfeed for pigs. Arch
Anim Nutr. 64 (6):437-66.doi: 10.1080/1745039X.2010.512725.

Mulijanti, S.L. S.Tedy danNurnayetti. 2014. Pemanfaatan Dedak Padi dan JeramiFermentasi pada Usaha Penggemukan Sapi Potong di Jawa Barat. Jurnal Peternakan Indonesia. 16 (3): 179-187.

Mussoline, W., G. Esposito, A. Giordano and P.N.L. Lens. 2012. The Anaerobic Digestion of Rice Straw: A Review. Critical Reviews in Environmental.Science and Technology 43(9) : 895-915. https://doi.org/10.1080/10643389.2011. $\underline{627018}$

Na, Y.J, I.H. Lee, S.S. Park and S.R. Lee. 2014. Effects of Combination of Rice Straw with Alfalfa Pellet on Milk Productivity and Chewing Activity in Lactating Dairy Cows. AsianAustralasian Journal of Animal Sciences. 27(7):960-964. doi:10.5713/ajas.2013.13597

Napasirth, V., P. Napasirth, T. Sulinthone, K. Phommachanhand Y. Cai. 2015. Microbial population, chemical compositionand silage fermentation of cassava residues. AnimalSciences Journal 86 (9): 279-280. doi: 10.1111/asj.12362. Epub 2015 Mar 17.

Ohmomo, S., O. Tanaka, H.K. Kitamoto andY. Cai. 2002. Silage and microbialperformance, Old story but newproblems. Japan Agricultural Research Quarterly 36(2): 59-71. DOI: $10.6090 /$ jarq.36.59

Oladosu, Y., M.Y. Rafii, N. Abdullah, U.Magaji, G. Hussin,A. Ramli and G. Miah. 2016.Fermentation Quality and Additives: A Case of Rice Straw Silage. BioMed Research International. $1-14$. http://dx.doi.org/10.1155/2016/798516 7

Pane, M.A., M. M. B. Damanik dan B. Sitorus. 2014. Pemberian Bahan Organik Kompos Jerami Padi dan Abu Sekam Padi dalam Memperbaiki Sifat 
Kimian Tanah Ultisol Serta Pertumbuhan Tanaman Jagung. Jurnal Online Agroekoteknologi . 2.(4): 1426 $-1432$

Rahman, M.A., A.M. Alam and M. Shahjalal. 2009. Supplementation of Urea-Molasses-Straw Based Diet with Different Levels of Concentrate for Fattening of Emaciated Bulls. Pakistan Journal of Biological Sciences, 12 (13): 970975.DOI: $10.3923 /$ pjbs.2009.970.975

Romli, M., Suprihatin, N. S. Indrasti dan A.Y. Aryanto. 2014. Pembentukan biogas dari jerami padi dan sampah pasar di dalam sistem fermentasi semi kering. Jurnal Teknologi Industri Pertanian 24 (2):97-104.

Roslan, A.M., P.L. Ye, U.K.M. Shah, S.A. Aziz and M.A. Hasan. 2011. Production of Bioethanol from Rice Straw using Cellulase by Local Aspergillus sp.International Journal of Agricultural Research 6(2):188193.DOI: 10.3923/ijar.2011.188.193

Saritha, M., R. Tiwari, S. Singh, S. Rana, A. Adak, A. Sharma, A. Arora and L. Nain. 2015. Bioprospecting for Superior Biomass Hydrolysing Fungi from Diverse Habitats. J Biodivers Biopros Dev 2 (2): 1-7 doi:10.4172/2376-0214.1000149

Sarnklong, C., J. W. Cone, W. Pellikaan and W. H. Hendriks. 2010. Utilization of Rice Straw and Different Treatments to Improve Its Feed Value for Ruminants: A Review. Asian-Aust. J. Anim. Sci. 23 (5) : 680-692. DOI: https://doi.org/10.5713/ajas.2010.8061 $\underline{9}$

Setiarto, R.H.B. 2013. Prospek dan potensi pemanfaatan lignoselulosa jerami padi menjadi kompos, silase dan biogas melalui fermentasi mikroba. Jurnal Selulosa. 3 (2): $51-66$.

Shanahan, J.F., D.H. Smith, T.L. Stanton and B.E. Horn. 2004. Crop Residues For Livestock Feed. Colorado :CSU Cooperative Extention- Agriculture, Colorado State University. http://www.ext. colostate.edu/pubs/ crop/00551.html

Sharma, M.N., A Khare and S.K. Gupta. 2001. Hydrolysis of rice hull by crosslinked Aspergillus nigercellulase. Bioresour Technol 78 (3): 281-284. https://doi.org/10.1016/S09608524(01)00010-4

Sheikh, G.G., A.M. Ganai, P.A. Reshi, S. Bilal andS. Mir.2018. Improved Paddy Straw as Ruminant Feed: A Review. JOJ scin. 1(1): 1-8.

Sheikh, G.G., A.M. Ganai, F.A. Sheikh, S.A. Bhat, D. Masood, S. Mir, I. Ahmad and M.A. Bhat. 2017. Effect of feeding urea molasses treated rice straw along with fibrolytic enzymes on the performance of Corriedale Sheep. Journal of Entomology and Zoology Studies. 5(6): 2626-2630

Shrivastava, B. P. Nandal, A. Sharma, K.K. Jain, Y.P. Khasa, T.K. Das, V. Mani, N.J. Kewalramani, S.S. Kundu and R.C. Kuhad. 2012. Solid state bioconversion of wheat straw into digestible and nutritive ruminant feed by Ganoderma sp. rckk02. Bioresour. Technol. 107: 347-351. https://doi.org/10.1016/j.biortech.2011. $\underline{12.096}$

Srithongkham, S., L. Vivitchanont and C. Krongtaew. 2012. Starch/cellulose biocomposites prepared by highshearhomogenization/compression molding. J Mater SciEng. B 2 (4): 213222.

Sugama, I.N.dan N.G. Budiari. 2012.Pemanfaatan Jerami Padi Sebagai Pakan Alternatifuntuk Sapi Bali Dara. Majalah Ilmiah Peternakan. 15 (1): 2125

Sun, Z.H., S. Liu, G.O. Tayo, S.X. Tang, Z.L. Tan, B. Lin, Z.X. He, X.F. Hang, Z.S. Zhou and M.Wang.2009. Effects of cellulase or lactic acid bacteria on silagefermentation and in vitro gas production of severalmorphological fractions of maize stover. Animal FeedScience \& Technology 152 (3-4): 219-231. 
https://doi.org/10.1016/j.anifeedsci.200 $\underline{9.04 .013}$

Sutama, I.K., T. Kostaman dan I. G.M. Budiarsana. 2006. Pengaruh Pakan Berbasis Jerami Padi terhadap Performan Beranak dan Produksi Susu Kambing Peranakan Etawah. Seminar Nasional Teknologi Peternakan dan Veteriner 2006. 550-554

Suwignyo, B. 2003. Penggunaan Complete Feed Berbasis Jerami Padi Fermentasi pada SapiAustralian Commercial Cross Terhadap Konsumsi Nutrien, Pertambahan BobotBadan, dan Kualitas Karkas. Tesis pada Program Pascasarjana, Fakultas Peternakan,Universitas Gadjah Mada, Yogyakarta.

Syamsu, J.A. 2006. Kajian Penggunaan StarterMikroba Dalam Fermentasi Jerami Padi Sebagai Sumber Pakan Pada PeternakanRakyat di Sulawesi Tenggara. Dalam Seminar Nasional Bioteknologi. Puslit BioteknologiLIPI: Bogor.

Utomo, R. 2004. Pengaruh penggunaan jerami padi fermentasi sebagai bahan dasar pembuatan pakan komplit pada kinerja domba. Buletin Peternakan 28 (4): 162-171

Van Soest, P.J. 2006. Rice straw, the role of silica andtreatments to improve quality. Anim Feed Sci Technol 130 (3-4):137171.

https://doi.org/10.1016/j.anifeedsci.200 6.01 .023

Wanapat, M., M. Chenost, F. Munoz and C. Kayouli. 1996. Methods forimproving the nutritive value of fibrous feed: Treatment andsupplementation. Ann. Zootech. 45 (Suppl 1):69103.DOI: 10.1051/animres: 19960621

Wanapat, M.,S. Kang, N. Hankla and K.Phesatcha.2013. Effect of rice straw treatment on feed intake, rumenfermentation and milk production in lactatingdairy cows. Afr. J. Agric. Res. Vol. 8(17):1677-1687. DOI: 10.5897/AJAR2013.6732
Wang, Y.S., W. Shi, L.T. Huang, C.L. Ding And C.C. Dai. 2016. The effect of lactic acid bacterial starter culture andchemical additives on wilted rice straw silage. Animal Science Journal87 (4): 525-535. doi: 10.1111/asj.12449

Watanabe, K. and K. Hayano, 1993. Distribution and identification ofproteolytic Bacillus spp. in paddy field soil under rice cultivation. Canadian Journal of Microbiology, 39(7): https://doi.org/10.1139/m93-097

Whitlow, L.W. and W.M. Hagler, Jr. 2002. Mycotoxins in feeds. Feedstuffs, 1072: 68-78.

Yanti, Y., B. Rahmi, T. Miyagi, S. Mizumachi, Surahmanto, Y.Kawamoto dan A.Purnomoadi. 2008.Nilai nutrisi jerami padi yang difermentasi dengan mikroorganisme pada suhu yangberbeda.Seminar Nasional Teknologi Peternakan dan Veteriner 2008

Yanuartono, H. Purnamaningsih, S. Indarjulianto dan A. Nururrozi. 2017. Potensi jerami sebagai pakan ternak ruminansia. Jurnal Ilmu-Ilmu Peternakan 27 (1): 40-62. DOI : 10.21776/ub.jiip.2017.027.01.05

Yazdi, M. K. S., A. Davoodabadi, H.R.K. Zarin, M.T. Ebrahimi and M.M.S. Dallal. 2017. Characterisation and probiotic potential of lactic acid bacteria isolated from Iranian traditional yogurts, Italian Journal of Animal Science. (162) :185-188, DOI: 10.1080/1828051X.2016.1222888

Yunilas. 2009. Karya Ilmiah. Bioteknologi Jerami Padi Melalui Fermentasi sebagai Bahan Pakan Ternak Ruminansia. Fakultas Pertanian, Universitas Sumatera Utara, Medan. repository.usu.ac.id/bitstream/handle/... /805/09E01417.pdf;.

Yoswathana, N., P. Phuriphipat, P. Treyawutthiwat and M. N. Eshtiaghi. 2010. Bioethanol Production from Rice Straw. Energy Research Journal 1 (1): 26-31 
Yusriani,Y. Elviwirda dan M. Sabri. 2015. Kajian Pemanfaatan Limbah Jerami Sebagai Pakan Ternak Sapi di Provinsi Aceh. Jurnal Peternakan Indonesia. 17 (2) : 163-169.

Zahiroddini, H., J. Baah, W, Absalom andT.A. McAllister. 2004. Effects of an inoculant and hydrolytic enzymes on fermentation and nutritive value of whole crop barley silageAnim. Feed
Sci. Technol. 117 (3):317-330.DOI: 10.1016/j.anifeedsci.2004.08.013

Zhang, J. G., H. Kawamoto and Y. M. Cai. 2010. Relationships between the addition ratesof cellulase or glucose and silage fermentation at different temperatures. Animal Science Journal. 81(3):325-330.

$10.1111 / \mathrm{j} .1740-$ 